\title{
Pengaruh Absensi Fingerprint dan Sanksi Hukuman Terhadap Disiplin Kerja Pegawai Pada Dinas Perdagangan Provinsi Sumatera Selatan
}

\author{
Emelda \\ STIE Rahmaniyah Sekayu,imeldaoedirman@yahoo.com
}

\begin{abstract}
ABSTRAK
Penelitian ini bertujuan untuk mengetahui Pengaruh Absensi Fingerprint dan sanksi hukuman terhadap Disiplin Kerja Pegawai Pada Dinas Perdagangan Provinsi Sumatera Selatan. Metode penelitian yang digunakan adalah metode penelitian kuantitatif, dengan populasi seluruh pegawai Kantor Dinas Perdagangan Provinsi Sumatera Selatan berjumlah 69 orang pegawai. Sampel yang digunakan dalam penelitian ini menggunakan teknik sampling jenuh sehingga diperoleh sampel sebanyak 69 pegawai. Teknik pengumpulan data dilakukan dengan observasi dan kuesioner. Teknik analisis data menggunakan analisis regresi linear berganda, koefisien determinasi, pengujian hipotesis uji t dan uji F. Hasil penelitian menunjukkan bahwa absensi fingerprint terhadap disiplin kerja diperoleh nilai signifikan 0,000 < signifikan 0,05 maka dapat disimpulkan secara parsial ada pengaruh yang signifikan antara absensi fingerprint terhadap disiplin kerja Pegawai pada Dinas Perdagangan Provinsi Sumatera Selatan. Variabel sanksi hukuman juga berpengaruh terhadap Disiplin Kerja dengan nilai signifikan $0,029<$ signifikan 0,05 . Hasil pengujian hipotesis uji $\mathrm{F}$ diperoleh nilai signifikan 0,000 0,05 maka hipotesis Ha (Hipotesis alternatif) diterima dan Ho (Hipotesis nol) ditolak, maka dapat disimpulkan bahwa secara bersama-sama ada pengaruh yang signifikan antara absensi fingerprint dan sanksi hukuman terhadap disiplin kerja pegawai pada Dinas Perdagangan Provinsi Sumatera Selatan.
\end{abstract}

Kata Kunci: absensi fingerprint, sanksi hukuman, disiplin kerja

\section{A. PENDAHULUAN}

Perkembangan teknologi tidak hanya meningkatkan informasi global saja, tetapi juga dapat membantu terciptanya media informasi dan telekomunikasi yang tidak mengenal batas ruang dan waktu. Kemajuan teknologi adalah sesuatu yang tidak dapat di hindari orang-orang di masanya, karena kemajuan teknologi akan selalu berjalan sesuai dengan kemajuan ilmu pengetahuan yang kita miliki. Pengaruh teknologi global sangat dirasakan manfaatnya bagi lembaga-lembaga yang berkepentingan, yakni dengan munculnya peralatan teknologi canggih yang digunakan untuk mempermudah kegiatan operasional lembaga.

Sumber daya manusia merupakan sangat berperan besar bagi kesuksesan suatu instansi. Unsur manusia dalam suatu organisasi dapat memberikan keunggulan dalam bersaing. Memiliki sumber daya manusia produktivitas dan kinerja yang tinggi merupakan impian setiap perusahaan atau instansi pemerintahan. Oleh karena itu peningkatan mutu sumber daya manusia merupakan hal yang paling penting bagi suatu perusahaan maupun instansi untuk pencapaian suatu tujuan instansi tersebut. Memiliki sumber daya manusia berkualitas dan sesuai dengan harapan maka akan memiliki daya saing yang tinggi. Untuk memperoleh sumber daya manusia yang berkualitas dan mempunyai daya saing yang tinggi diperlukan faktorfaktor penentunya, kinerja yang baik didukung oleh disiplin kerja yang baik, karena untuk mencapai setiap tujuan yang telah ditetap oleh suatu instansi dibutuhkan kualitas sumber daya manusia yang terencana dengan baik. 
Hal ini dikarenakan sumber daya manusia merupakan pelaku utama dalam menentukan keberhasilan pada suatu instansi pemerintahan dalam mencapai tujuan yang telah tetapkan.

Dalam upaya meningkatkan kedisiplinan kerja pegawai negeri sipil, pemerintah telah membuat suaturegulasi dengan adanya Peraturan Pemerintah Nomor. 30 Tahun 1980 yang telah diperbaharui dengan Peraturan Pemerintah Nomor. 53 Tahun 2010 tentang peraturan disiplin pegawai negeri sipil. Kemudian pemerintah menerbitkan UndangUndang Nomor 5 Tahun 2014 tentang ASN pada paragraf 11 pasal 86 tentang disiplin Aparatur Sipil Negara. Tetapi pada umumnya PNS dirasakan masih kurang mematuhi peraturan kedisiplinan pegawai sehingga dapat menghambat kelancaran pemerintahan dan pembangunan nasional.

Dalam menjalankan fungsi dan tugasnya, instansi membutuhkan tenaga kerja untuk menjalankan seluruh aktifitas yang ada, sehingga dapat mencapai target-target pekerjaan. Pegawai yang baik adalah pegawai yang patuh dan disiplin pada aturan lembaga, untuk itu pimpinan perlu memantau dan menggerakkan kedisiplinan pegawai agar dapat berjalan maksimal. Salah satu ukuran kedisiplinan kerja pegawai pimpinan menerapkan sistem absensi agar lebih mudah mengontrol dan mengkalkulasi jumlah kehadiran.

Handoko (2012:41) menyatakan kedisiplinan pegawai adalah sifat seorang pegawai yang secara sadar mematuhi aturan dan peraturan organisasi tertentu. Kedisiplinan seharusnya dipandang sebagai bentuk latihan bagi pegawai dalam melaksanakan aturan-aturan organisasi. Semakin disiplin semakin tinggi produktivitas kerja karyawan dan kinerja organisasi. Hasibuan (2013:66) menyatakan ada beberapa faktor yang berhubungan dengan disiplin kerja diantaranya yaitu tujuan dan kemampuan, keteladanan pemimpin, balas jasa, keadilan, pengawasan, sanksi hukuman, ketegasan dan hubungan kemanusiaan.

Sistem absensi merupakan salah satu bentuk pengawasan kedisiplinan yang sudah banyak digunakan dan diterapkan oleh berbagai instansi maupun perusahaan. Salah satu absensi yang sering digunakan adalah absensi sidik jari (fingerprint). Menurut Tofik (2010:9), absensi sidik jari (fingerprint) adalah perangkat untuk mencatat tanggal dan jam keluar/masuk karyawan melalui penempelan sidik jari. Biasanya yang ditempelkan adalah jempol tangan. Penggunaan absensi fingerprint tidak bisa di manipulasi ataupun dibohongi, oleh karna itu sistem absensi fingerprint sudah banyak di gunakan dalam instansi ataupun perusahaan.

Dalam rangka menertibkan kedisiplinan pegawai, instansi juga perlu memberikan sanksi hukuman agar memberikan efek jera bagi pegawai. lakukan pengawasan kepada pegawai agar dapat menjalankan tugas dengan sebaik-baiknya. Rivai dan Jauvani (2014) menyatakan sanksi adalah hukuman disiplin yang dijatuhkan pimpinan organisasi kepada pegawai yang melanggar peraturan.

Upaya yang dilakukan pimpinan Dinas Perdagangan Provinsi Sumatera Selatan dalam rangka menegakkan kedisiplinan pegawainya dengan menerapkan sistem absensi fingerprint yang mulai diberlakukan pada tanggal 2 Januari 2018 hingga sekarang. Penerapan sistem absensi ini juga sebagai upaya dalam memudahkan atasan untuk melihat tingkat kedisiplinan pegawai di Dinas Perdagangan Provinsi Sumatera Selatan. Karena selama ini 
penggunaan sistem absensi manual tidak bisa mendata secara sempurna kapan pegawai datang dan pulang, atau pegawai bisa saja menitipkan absen kepada pegawai lainnya. Sehingga tindakan demikan akan menyulitkan atasan dalam memberi sanksi hukuman bagi pegawai yang melakukan pelanggaran sesuai dengan peraturan pemerintah No. 53 tahun 2010 tentang disiplin Pegawai Negeri Sipil.

Persentase pelanggaran yang dilakukan pegawai Dinas Perdagangan Sumatera Selatan pada saat menggunakan absensi manual sangat tinggi, berdasarkan data absensi yang penulis dapatkan dari objek penelitian tindak pelanggaran yang dilakukan pegawai seperti datang dan pulang tidak tepat waktu, pegawai yang berada diluar kantor saat jam kerja untuk urusan pribadi maupun urusan intansi tanpa izin atasan, ataupun pegawai yang tidak masuk tanpa keterangan. Kondisi tersebut merupakan tindak pelanggaran kedisiplinan yang dilakukan pegawai karena kurangnya pengawasan terhadap sikap disiplin pegawai. Jika masalah ini dibiarkan terus berlanjut pada lembaga/instansi pemerintahan maka akan menimbulkan masalah bagi lembaga yang pada akhirnya lembaga tersebut tidak dapat mencapai tujuannya. Dari hasil fenomena pelanggaran tersebut peneliti bermaksud ingin mengetahui setelah menggunakan absensi fingerprint apakah pelanggaran pegawai masih tetap tinggi atau pegawai mengalami perubahan menjadi lebih disiplin.

Berdasarkan uraian pada latar belakang, maka penulis tertarik untuk menganalisis lebih lanjut mengenai penelitian berjudul: "Pengaruh Absensi Fingerprint dan Sanksi Hukuman terhadap Disiplin Kerja

\section{Pegawai pada Dinas Perdagangan Provinsi Sumatera Selatan".}

\section{B. LANDASAN TEORI}

1) Absensi Fingerprint

Kasmir (2016:204) menyatakan bahwa absensi merupakan keberadaan atau bukti kehadiran karyawan pada saat masuk jam kerja sampai dengan pulang kerja. Sedangkan Haqi dan Setiawan (2019:104) menyatakan absensi atau kartu jam hadir adalah dokumen yang mencatat jam hadir setiap karyawan di perusahaan.

Menurut Tofik (2010:9), absensi sidik jari (fingerprint) adalah perangkat untuk mencatat tanggal dan jam keluar/masuk karyawan melalui penempelan sidik jari. Biasanya yang ditempelkan adalah jempol tangan. Alat ini dilengkapi dengan software untuk melakukan perekaman atas transaksi yang terjadi. Prinsipnya adalah bahwa pencatatan masuk/keluar karyawan akan tercatat secara elektris dimedia kertas maupun langsung berupa file elektris. Nugroho (2012:17) Absensi adalah daftar kehadiran pegawai/siswa/guru yang berisi jam datang dan jam pulang serta alasan atau keterangan kehadiran. Absensi ini berkaitan dengan penerapan disiplin yang ditentukan oleh masing-masing perusahaan atau institusi. Fingerprint berasal dari bahasa inggris yang berarti sidik jari. Sidik jari adalah gurat-gurat yang terdapat dikulit ujung jari. Sidik jari berfungsi untuk memberi gaya gesek lebih besar agar jari dapat memegang benda lebih erat.

Dari pengertian diatas, dapat disimpulkan bahwa absensi fingerprint adalah alat untuk mendata kehadiran pegawai pada saat datang dan pulang berdasarkan sidik jari pegawai secara langsung dan tidak dapat diwakilkan. Sifat absensi yang harus berhubungan 
langsung dengan orang yang bersangkutan adalah cara agar tidak terjadi manipulasi atau kecurangan dari individu yang bersangkutan.

\section{2) Indikator Absensi Fingerprint}

Davis (2012:3), mesin absensi sidik jari (fingerprint) merupakan sistem informasi manajemen yang mengandung elemen-elemen fisik seperti yang mengenai Sistem Informasi Manajemen adalah sebagai berikut:

a) Perangkat keras komputer, terdiri atas komputer pusat pengelola, unit masukan keluaran, unit penyimpanan, file dan peralatan penyimpanan data.

b) Database, data yang tersimpan dalam media penyimpanan komputer.

c) Prosedur, komponen fisik karena prosedur disediakan dalam bentuk fisik seperti buku dan instruksi.

d) Personalia pengoperasian, seperti operator komputer, analisis sistem pembuatan program, personalia penyimpanan data dan pimpinan sistem informasi.

\section{3) Sanksi Hukuman}

Mangkunegara

\section{"punishment adalah}

(2000:130) hukuman yang bertujuan untuk memperbaiki kinerja karyawan pelanggar, memelihara peraturan yang berlaku dan memberikan pelajaran kepada pelanggar. Menurut Ivancevich, (2006:226) "punishment didefinisikan sebagai tindakan menyajikan konsekuensi yang tidak menyenangkan atau tidak diinginkan sebagai hasil dari dilaukannya prilaku tertentu. Dari definisi diatas dapat disimpulkan bahwa sanksi hukuman (punishment) adalah konsekuensi yang akan didapat bagi pelanggar kedisiplinan setelah sebelumnya diberikan peringatan dan ancaman sebagai penunjang dalam merubah sikap dan prilaku dalam berdisiplin agar penegakan aturan kedisiplinan tetap berjalan dengan baik. Pada umumnya sebagai pegangan pemimpin meskipun tidak mutlak, tingkat dan jenis sanksi disiplin kerja yang dikemukakan Rivai (2014:293) terdiri atas sanksi disiplin berat, sanksi disiplin sedang dan sanksi disiplin ringan.

1. Sanksi disiplin berat,

a. Demosi jabatan yang setingkat lebih rendah dari jabatan atau pekerjaan yang diberikan sebelumnya

b. Pembebasan dari jabatan atau pekerjaan untuk dijadikan sebagai tenaga kerja biasa bagi memegang jabatan

c. Pemutusan hubungan kerja dengan hormat atas permintaan sendiri tenaga kerja yang bersangkutan

d. Pemutusan hubungan dengan tidak hormat sebagai tenaga kerja diorganisasi atau perusahaan

2. Sanksi disiplin sedang, misalnya :

a. Penundaan pemberian kompensasi yang sebelumnya telah direncanakan sebagaimana tenaga kerja lain

b. Penurunan upah atau gaji sebesar satu kali upah atau gaji yang biasanya diberikan harian, mingguan, atau bulanan

c. Penundaan program promosi bagai bagi tenaga kerja yang bersangkutan pada jabatan yang lebih tinggi

3. Sanksi disiplin ringan, misalnya :
a. Teguran lisan kepada tenaga kerja yang bersangkutan
b. Teguran tertulis
c. Pernyataan tidak puas secara tertulis.




\section{4) Disiplin Kerja}

Sutrisno (2014:86), disiplin kerja adalah sikap kesediaan dan kerelaan seseorang untuk mematuhi dan menaati norma-norma peraturan yang berlaku di sekitarnya. Disiplin karyawan yang baik akan mempercepat tujuan perusahaan, sedangkan disiplin yang merosot akan menjadi penghalang dan memperlambat pencapaian tujuan perusahaan. Hasibuan (2014:193), disiplin kerja adalah kesadaran dan kesediaan seseorang menaati semua peraturan perusahaan dan normanorma sosial yang berlaku. Kesadaran dalah sikap seseorang yang secara sukarela menaati semua peraturan dan sadar akan tugas dan tanggung jawabnya. Jadi, dia akan mematuhi/mengerjakan semua tugasnya dengan baik, bukan atas paksaan. Kesediaan adalah suatu sikap, tingkah laku, dan perbuatan seseorang yang sesuai dengan peraturan perusahaan, baik yang tertulis maupun tidak.

Menurut Sinambela (2017:334), disiplin kerja adalah kepatuhan pada aturan atau perintah ditetapkan oleh organisasi. Selanjutnya, disiplin adalah sebuah proses yang digunakan untuk menghadapi permasalahan kinerja, proses ini melibatkan melibatkan manager dalam mengidentifikasi dan mengomunikasikan masalah-masalah kinerja kepada para pegawai.

Dari beberapa uraian di atas dapat disimpulkan bahwa disiplin kerja adalah bentuk ketaatan dan kepatuhan seseorang terhadap tanggung jawab pekerjaannya, tanpa mengharap balas jasa dari atasannya.

\section{METODE PENELITIAN}

Lokasi penelitian merupakan tempat dimana peneliti melakukan penelitian untuk memperoleh data-data yang diperlukan. Adapun lokasi penelitian ini dilaksanakan di Dinas Perdagangan Provinsi Sumatera Selatan, yang beralamat di Jalan Demang Lebar Daun, No 2610, Bukit Baru, llir Barat, Kota Palembang Sumatera Selatan.

Dalam penelitian ini, metode penelitian yang digunakan adalah metode penelitian kuantitatif. Menurut Sugiyono (2013:13) Metode penelitian kuantitatif dapat diartikan sebagai metode penelitian yang berlandaskan pada filsafat positivisme, digunakan untuk meneliti pada populasi atau sampel tertentu, teknik pengambilan sampel pada umumnya dilakukan secara random, pengumpulan data menggunakan instrumen penelitian, analisis data bersifat kuantitatif/statistik dengan tujuan untuk menguji hipotesis yang telah ditetapkan.

Populasi adalah seluruh Pegawai Negeri Sipil (PNS) yang ada di Dinas Perdagangan Provinsi Sumatera Selatan adalah 69 orang pegawai, penentuan sampel menggunakan teknik sampling jenuh. Menurut Sugiyono (2013:122) sampling jenuh adalah tehnik penentuan sampel bila semua anggota populasi digunakan sebagai sampel. Hal ini sering dilakukan bila jumlah populasi relatif kecil. Mengingat jumlah populasi dalam penelitian ini berjumlah 69 maka layak untuk di ambil seluruhnya sebagai sampel. Dalam penelitian ini jumlah sampel sebanyak 69 orang pegawai.

Menurut Sugiyono (2013:275) analisis regresi linier berganda digunakan untuk mengetahui pengaruh atau hubungan secara linier antara satu variabel independen dengan satu variabel dependen. Persamaan regresi linier sederhana dalam penelitian ini digunakan untuk mengetahui seberapa besar pengaruh Absensi fingerprint $\left(\mathrm{X}_{1}\right)$ terhadap disiplin kerja $(\mathrm{Y})$ dan 
sanksi hukuman $\left(\mathrm{X}_{2}\right)$ terhadap disiplin $\operatorname{kerja}(\mathrm{Y})$.

\section{HASIL PENELITIAN DAN PEMBAHASAN}

1. Pengaruh Absensi Fingerprint terhadap Disiplin Kerja Pegawai pada Dinas Perdagangan Provinsi Sumatera Selatan.

Hasil uji t untuk variabel Absensi Fingerprint $\left(\mathrm{X}_{1}\right)$ terhadap Disiplin Kerja (Y) diperoleh nilai signifikan 0,000< 0,05 yang berarti Ho ditolak dan $\mathrm{Ha}$ diterima. Dengan demikian berarti bahwa secara parsial ada pengaruh yang signifikan antara Absensi Fingerprint terhadap Disiplin Kerja pegawai pada Dinas Perdagangan Provinsi Sumatera Selatan.

Hasil penelitian ini berkesesuian dengan hasil penelitian Suwandi dan Hariadi (2018) yang menyatakan bahwa secara parsial absensi fingerprint mempunyai pengaruh yang signifikan terhadap disiplin kerja pada suatu perusahaan/instansi.

Hasil penelitian ini menunjukkan bahwa melalui penerapan absensi fingerprint disiplin kerja pegawai lebih mudah dicapai. Hal ini berkaitan dengan pendapat Nugroho (2012:17) yang menyatakan bahwa absensi fingerprint adalah daftar kehadiran pegawai/siswa/guru yang berisi jam datang dan jam pulang serta alasan atau keterangan kehadiran. Absensi ini berkaitan dengan penerapan disiplin yang ditentukan oleh masing-masing perusahaan atau institusi.

\section{Pengaruh Sanksi Hukuman terhadap Disiplin Kerja Pegawai pada Dinas Perdagangan Provinsi Sumatera Selatan.}

Hasil uji t untuk variabel Sanksi Hukuman secara parsial antara variabel Pengawasan Internal $\left(X_{2}\right)$ terhadap Disiplin Kerja (Y) diperoleh nilai signifikan $0,029<0,05$ yang berarti Ho ditolak dan $\mathrm{Ha}$ diterima. Dengan demikian berarti bahwa secara parsial ada pengaruh yang signifikan sanksi hukuman terhadap Disiplin Kerja pegawai pada Dinas Perdagangan Provinsi Sumatera Selatan.

Hasil penelitian ini berkesesuian dengan hasil penelitian Nuryadin (2016) yang menyatakan bahwa secara parsial sanksi hukuman mempunyai pengaruh yang signifikan terhadap disiplin kerja pada suatu perusahaan/instansi. Hasil penelitian ini menunjukkan bahwa sanksi hukuman dapat memberikan efek jera bagi pegawai. Dinas Perdagangan Provinsi Sumatera Selatan telah menerapkan peraturan sesuai UndangUndang Nomor 5 Tahun 2014 tentang ASN pada paragraf 11 pasal 86 tentang disiplin Aparatur Sipil Negara. Hal ni memberikan motivasi bagi pegawai karena setiap apa yang mereka kerjakan memiliki konsekuensi berupa reward dan punishment, jadi bagi pegawai yangmemiliki kedisiplinan kerja yang tinggi akan mendapatkan penghasilan yang berbeda denganpegawai yang belum memiliki kedisiplinan kerja yang tinggi. Oleh karena itu dibutuhkankomitmen pimpinan organisasi dalam penerapan, pemberian serta penegakan aturan secara konsisten, adil dan transparan mengenaiapa yang boleh dan apa yang tidak boleh dilakukan.

\section{E. PENUTUP \\ 1) Kesimpulan \\ Berdasarkan hasil dan analisis data yang telah diuraikan, maka dapat simpulkan sebagai berikut:}

a) Terdapat pengaruh absensi fingerprint terhadap disiplin kerja 
pegawai di Dinas Perdagangan Provinsi Sumatera Selatan.

b) Terdapat pengaruh sanksi hukuman berpengaruh terhadap disiplin kerja pegawai di Dinas Perdagangan Provinsi Sumatera Selatan.

c) Terdapat pengaruh absensi fingerprint dan sanksi hukuman terhadap disiplin kerja pegawai di Dinas Perdagangan Provinsi Sumatera Selatan.

\section{2) Saran}

Berdasarkan kesimpulan diatas, penulis mencoba mengajukan beberapa saran yang diharapkan dapat menjadi masukan atau bahan pertimbangan bagi pihak Dinas Perdagangan Provinsi Sumatera Selatan adalah sebagai berikut:

a) Hendaknya Dinas Perdagangan Provinsi Sumatera Selatan dapat terus menerapkan absensi fingerprint dan selalu meninjau, memantau dan memperbaiki sistem pelaksanaan absensi fingerprint, agar dapat meningkatkan disiplin pegawai.

b) Terapkan pemberian punishment secara adil tanpa pandang strata, ras dan golongan, agar yidak menimbulkan kecemburuan sosial dan pembangkangan pegawai. Berikan reward bagi pegawai yang disiplin tinggi, agar dapat memotivasi pegawai yang pemalas.

\section{DAFTAR PUSTAKA}

Bay Haqi dan Heri Satria Setiawan. Aplikasi Absensi Dosen Dengan Java dan Smartphone Sebagai Barcode Reader. Jakarta: PT Elek Media Komputindo.
Davis, b, Gordon. 2012. Kerangka Dasar Sistem Informasi Manajemen Bagian II Stuktur dan Pengembangan. Jakarta: PT Pustaka Binaman Pressindo.

Hasibuan, Melayu S.P. 2014. Manajemen Sumber Daya Manusia. Jakarta: PT Bumi Aksara.

Handoko, T, Hani. 2012. Manajemen Sumber Daya Manusia. Yogyakarta: BPFE.

Hariadi, Putri Sheila Lubna. 2018. Efektivitas Penerapan Absensi Fingerprint dan Sanksi Dalam Meningkatkan Disiplin Kerja Karyawan Kantor PT. Rimba Perkasa Utama Samarinda, Jurnal (Online) Administrasi Bisnis ISSN 2355-5408 Vol 4 No 6, (http://ejournal.adbisnis.fisipunmul.ac.id, diakses 07 November 2018)

Kasmir. 2016. Manajemen Sumber Daya Manusia Teori dan Praktik. Jakarta: Raja Grafindo Persada.

Mangkunegara, Anwar Prabu. 2000. Manajemen Sumber Daya Manusia. Bandung: remaja Rosda Karya

Nuryadin, Syahrial \& Agusdin \& Suprayetno, Djoko. 2016. Pengaruh Kepemimpinan, Pengawasan, Sanksi Hukuman terhadap Kedisiplinan Kerja Pegawai di Sekretariat Daerah Kota Bima. Jurnal Magister Manajemen Universitas Mataram. Vol. 2 (1) hal: 1-14

Peraturan Pemerintah No.53 Tahun 2010. Peraturan Pegawai Negeri Sipil 
Rivai, Veitzhal \& Ella Juavani. 2014. Manajemen Sumber Daya Manusia. Jakarta: Raja grafindo Persada

Sutrisno, Edy. 2014. Manajemen Sumber Daya Manusia. Jakarta: Kencana Predana Media Group.

Suwandi, Tambunan, Yusuf. 2018. Pengaruh Penerapan Absensi Fingerprint Terhadap Disiplin Kerja Pada PT Telkom Indonesia Jakarta. Jurnal (Online) IImu Manajemen Vol 1 No 2 ,(http://journal.stie-

Sinambela, Lijan Poltak. 2017. Manajemen Sumber Daya Manusia. Jakarta: PT Bumi Aksara.

Sugiyono. 2013. Metodelogi Penelitian Bisnis. Bandung: Alfabeta.

Topik, Moch. 2010. Panduan Praktis Membuat Aplikasi Penggajian Dengan Excel 2007. Jakarta: Media Kita.

Undang-Undang No.5 Tahun 2014. Disiplin Aparatur Sipil Negara (ASN) Agusuts 2018) 